\title{
KOMPETENSI PEDAGOGIK GURU MATEMATIKA SMA DI PENAJAM PASER UTARA
}

\author{
Dea Talitha ${ }^{1}$, Sugianto ${ }^{2}$, Mochammad Alipatan ${ }^{3}$ \\ Universitas Balikpapan ${ }^{1}$, Universitas Balikpapan ${ }^{2}$, Universitas Balikpapan ${ }^{3}$ \\ pos-el:deajuli1998@gmail.com ${ }^{1}$, sugianto@uniba-bpn.ac.id ${ }^{2}$, alipatan9@yahoo.co.id ${ }^{3}$
}

\begin{abstract}
ABSTRAK
Kompetensi pedagogik guru matematika merupakan kemampuan guru matematika dalam memahami peserta didik untuk menentukan tingkat keberhasilan proses dan hasil pembelajaran peserta didiknya.. Oleh karena itu, penguasaan guru matematika terhadap kompetensi pedagogik ini sangat berpengaruh dalam mengelola pembelajaran peserta didik. Tujuan penelitian ini adalah untuk menggambarkan kompetensi pedagogik guru matematika di SMA Negeri 1 Kabupaten Penajam Paser Utara. Data dijaring menggunakan observasi, wawancara, dokumentasi. Hasil penelitian diperoleh: (1) guru matematika memberi kesempatan yang sama kepada peserta didik untuk berpartisipasi aktif dalam kegiatan pembelajaran, dan belum optimal mengenali lebih dalam perkembangan anak didiknya (minat, bakat) yang beragam, (2) guru matematika memastikan tingkat pemahaman peserta didik dengan quipper school, (3) guru matematika dapat menyusun silabus sesuai kurikulum yang dibuat bersama melalui forum MGMP selanjutnya merancang RPP, (4) guru matematika melakukan aktivitas pembelajaran secara bervariasi dan memberi banyak kesempatan untuk bertanya, memberikan contoh, dan mempraktikkan soal, (5) guru matematika merancang bentuk penilaian sesuai tingkat kemajuan peserta didik tetapi kurang optimal mengidentifikasi tentang bakat minat potensi peserta didik, 6) guru matematika berkomunikasi secara empatik dengan memberi perhatian dan mendengarkan semua pertanyaan dan tanggapan peserta didik, (7) guru matematika menyusun alat penilaian sesuai alat pembelajaran dengan berbagai teknik dan jenis penilaian tetapi tidak dilakukan analisis penilaian.
\end{abstract}

\section{Kata kunci : Kompetensi pedagogik, Matematika}

\begin{abstract}
Mathematics teacher pedagogical competence is the mathematics teacher's ability to understand students to determine the success rate of the learning process and outcomes of their students. Therefore, the mastery of mathematics teachers on pedagogic competences is very influential in managing student learning. The purpose of this study was to describe the pedagogical competence of mathematics teachers in SMA Negeri 1 Penajam Paser Utara Regency: Data were collected using observation, interviews, documentation. The results of the research were: (1) the mathematics teacher provided equal opportunities for students to actively participate in learning activities, and had not optimally identified more deeply the development of their students (interests, talents) that were diverse, (2) the mathematics teacher ensured the level of understanding of students. with the quipper school, (3) the mathematics teacher can compile a syllabus according to the curriculum that is made jointly through the MGMP forum then to design the lesson plan, (4) mathematics teachers carry out various learning activities and provide many opportunities to ask questions, give examples, and practice question problems, (5) the mathematics teacher was planning the form of assessment according to the level of progress of student but not optimally identifies the talents of potential interest of students, 6) mathematics teachers communicate emphatically by paying attention and listening to all questions and responses of students, (7) the mathematics teacher prepared an assessment tool according to the learning tool with various techniques and types of assessment but no assessment analysis was carried out.
\end{abstract}

Keywords: Pedagogic competence, Mathematics 


\section{PENDAHULUAN}

Guru sebagai seorang pendidik merupakan profesi yang mulia, karena di tangan pendidik kualitas sumber daya manusia dibangun. Kunci utama rendah tingginya kualitas pendidikan terletak pada guru. Seiring dengan kemajuan teknologi informasi, telah meningkatkan fleksibilitas dalam pemerolehan ilmu pengetahuan bagi setiap individu baik guru ataupun siswa. Konsekuensinya, guruguru dituntut mampu mengembangkan pendekatan dan strategi pembelajaran yang sesuai dengan perkembangan lingkungan sebagai kompetensi guru abad 21. Kompetensi pedagogik adalah seni mengajar guru, dalam hal pembelajaran kurangnya kemampuan guru untuk menggunakan TIK membawa dampak pada siswa, didasarkan pada kenyataan bahwa substansi materi pelajaran yang harus dipelajari oleh anak didik terus berkembang baik volume maupun kompleksitasnya. Demikian juga guru dalam kompetensi ini memiliki kemampuan mengoptimalkan potensi peserta didik untuk mengaktualisasikan minatnya dalam pembelajaran matematika. Di sini guru dituntut dukungan strategi dan teknologi pembelajaran yang secara terus-menerus.

Berdasarkan observasi pendahuluan dan wawancara bahwa kompetensi yang dimiliki guru matematika SMA Negeri 1 Kabupaten Penajam Paser Utara cukup baik. Semuanya di atas 80 dengan ditunjukkan nilai kinerja guru yang dibuat akhir tahun, dan guru matematika yang sudah bersertifikasi pendidik yang terdapat di SMA Negeri 1 sebanyak 4 (empat). Selanjutnya mengenai karakteristik siswa di sini beragam, dengan berbagai latar belakang tentu saja ada yang aktif, pendiam super aktif, ditambahkan guru dalam mengidentifikasi karakteristik peserta didik diperlukan waktu yang cukup lama dan guru matematika perlu bekerja sama dengan guru BK untuk mengetahui dengan baik mengenai karakter peserta didik tersebut sehingga mengenal karakteristik peserta didik masih terus ditingkatkan, karena terus terang saja untuk hafal nama perlu waktu. Kemudian ketika ditanyakan tentang penguasaan teori belajar, semua kurang mampu menjelaskan dengan baik teori konstrutivistik, sedikit tahu tentang model pembelajaran, beliau hanya menjelaskan peserta didik berbeda-beda, ada yang menyukai matematika dan tidak sehingga tidak bisa dipaksakan namun pemberian motivasi belajar tetap diberikan.

Kompetensi pedagogik adalah seni mengajar guru, dalam hal pembelajaran kurangnya kemampuan guru untuk menggunakan TIK membawa dampak pada siswa, didasarkan pada kenyataan bahwa substansi materi pelajaran yang harus dipelajari oleh anak didik terus berkembang baik volume maupun kompleksitasnya. Demikian juga guru dalam kompetensi ini memiliki kemampuan mengoptimalkan potensi peserta didik untuk mengaktualisasikan minatnya dalam pembelajaran matematika. Di sini guru dituntut dukungan strategi dan teknologi pembelajaran yang secara terus-menerus. Lebih lanjut, dalam Permendiknas No 16 Tahun 2007 tentang Standar Pendidik dan Kependidikan dikemukakan bahwa kompetensi pedagogik merupakan kemampuan guru dalam pengelolaan pembelajaran siswa yang meliputi hal-hal sebagai berikut: menguasai karakteristik peserta didik, menguasai teori belajar dan prinsip-prinsip pembelajaran yang mendidik (kemampuan mengelola pembelajaran), mengembangkan kurikulum yang terkait dengan bidang pengembangan yang diampu, menyelenggarakan kegiatan pengembangan yang mendidik dan dialogis, memanfaatkan teknologi informasi dan komunikasi untuk kepentingan penyelenggaraan kegiatan pengembangan yang mendidik, memfasilitasi pengembangan potensi peserta didik untuk mengaktualisasikan berbagai potensi yang dimiliki, 
berkomunikasi secara efektif, empatik dan santun dengan peserta didik, menyelenggarakan penilaian dan evaluasi proses dan hasil belajar, memanfaatkan hasil penilaian dan evaluasi untuk kepentingan pembelajaran, serta melakukan Tindakan reflektif untuk peningkatan kualitas pembelajaran.

Penelitian serupa pernah dilakukan dengan judul Deskripsi Kompetensi Pedagogik Guru dan Calon Guru Kimia SMA Muhammadiyah 1 Semarang oleh Ade Kurniawan (2017) dengan hasil penelitian menunjukkan terdapat perbedaan yang sangat menonjol antara kompetensi pedagogik guru dan calon guru dalam hal pengetahuan akan pemahaman peserta didik dalam kimia, dan pengetahuan terhadap strategi dan representasi pembelajaran untuk mengajarkan kimia. Selain itu penelitian yang dilakukan oleh Rista Sumaryaning Dewi (2016) dengan judul Analisis Kompetensi Pedagogik Guru Dalam Pelaksanaan Kurikulum 2013 Pada Pembelajaran Tematik Tema Sehat Itu Penting Kelas $\mathrm{V}$ di $\mathrm{SD} \mathrm{Hj}$. Isriati Baiturrahman 1 Semarang Tahun Ajaran 2015/2016" yang menyimpulkan bahwa belum terpenuhi seluruhnya dari indikator kompetensi pedagogik.

Berdasarkan berbagai penelitian relevan tersebut, kemudian faktor-faktor peneliti diarahkan dengan fokus kompetensi pedagogik yaitu kemampuan mengelola pembelajaran, pemahaman terhadap siswa, perancangan pembelajaran, pembelajaran mendidik dan dialogis, pemanfaatan teknologi, evaluasi hasil belajar, pengembangan siswa. Faktor-faktor apa atau nilai dominan apakah yang berpengaruh dalam kompetensi pedagogik guru matematika di SMA Negeri 1 Kabupaten Penajam Paser Utara, dengan begitu peneliti diharapkan dapat memperjelas langkah-langkah dalam pengajaran bidang kompetensi pedagogik.

Berdasarkan 10 indikator kompetensi pedagogik, peneliti meneliti 7 indikator sesuai PKG (Penilaian Kinerja Guru).
Oleh karena itu, tujuan penelitian ini yaitu untuk menggambarkan penguasaan karakteristik peserta didik, penguasaan teori pembelajaran dan prinsip-prinsip pembelajaran yang mendidik, pengembangan kurikulum yang terkait dengan bidang pengembangan yang diampu, penyelenggaraan kegiatan pengembangan yang mendidik dan dialogis, fasilitas pengembangan potensi peserta didik untuk mengaktualisasikan berbagai potensi yang dimiliki, komunikasi secara efektif, empatik, dan santun dengan peserta didik, penyelenggaraan penilaian dan evaluasi proses dan hasil belajar dalam kompetensi pedagogik guru matematika di SMA Negeri 1 Kabupaten Penajam Paser Utara.

\section{METODE PENELITIAN}

Pendekatan penelitian adalah pendekatan kualitatif ialah salah satu prosedur penelitian yang menghasilkan data deskriptif berupa ucapan atau tulisan dan perilaku orang-orang yang diamati dalam suatu konteks tertentu yang dikaji dari sudut pandang yang utuh, komprehensif dan holistik. Jenis penelitian yaitu metode deskriptif kualitatif dimaksudkan untuk mengumpulkan informasi mengenai status suatu gejala yang ada, yaitu keadaan gejala menurut apa adanya pada saat penelitian dilakukan. Sumber data dalam penelitian ini adalah informan adalah: Kepala sekolah SMA Negeri 1, dan 3 (tiga) guru matematika SMA Negeri 1. Peneliti memilih informan tersebut sebagai sumber data karena informan menguasai dan mengetahui profesionalisme guru khususnya bidang kompetensi pedagogik. Teknik pengumpulan data kualitatif yaitu pengumpulan data-data yang bersifat deskriptif yaitu data berupa gejala hasil wawancara atau observasi instrumen pengumpulan data berupa telepon genggam, pensil, pulpen, buku, selain itu pedoman observasi, pedoman wawancara, pedoman dokumentasi. Keabsahan datanya dengan melakukan perpanjangan 
pengamatan, meningkatkan ketekunan, dan triangulasi. Teknik analisis data dilakukan pada saat wawancara, peneliti sudah melakukan analisis terhadap jawaban yang diwawancarai. Bila jawaban yang diwawancarai setelah dianalisis terasa belum memuaskan, maka peneliti akan melanjutkan pertanyaan lagi, sampai tahap tertentu, diperoleh data yang dianggap kredibel.

\section{HASIL DAN PEMBAHASAN}

Penguasaan karakteristik peserta didik menggunakan deskriptif kualitatif dengan metode wawancara via whatsapp video call. Guru matematika SMA Negeri 1 Penajam mengidentifikasi karakteristik peserta didik saat proses pembelajaran di kelas, artinya membutuhkan waktu yang cukup lama untuk bisa memahami karakteristik semua peserta didik dan memerlukan bantuan dari guru BK (Bimbingan Konseling).

Guru harus memberikan kesempatan yang sama untuk berpartisipasi aktif saat pembelajaran berlangsung, artinya guru bertanya kepada semua peserta didik agar mereka memiliki kesadaran sendiri untuk menjawab pertanyaan yang akan membantu perkembangan kemampuan intelektualnya. Hal ini senada dengan apa yang dikemukakan oleh Paul B. Diedrich dalam (Sardiman, 2010, p.101) bahwa partisipasi aktif siswa dalam proses pembelajaran dapat diwujudkan dalam mendengarkan uraian, mencatat penjelasan guru, bertanya, menjawab pertanyaan, menjelaskan kembali, menanggapi atau berpendapat, dan bersemangat.

Guru matematika SMA Negeri 1 memberikan kesempatan yang sama kepada peserta didik ditujukan dengan kegiatan pembelajaran yang dilakukan dalam bentuk tanya jawab memanggil peserta didik secara acak. Dengan tujuan untuk memberikan kesempatan bagi setiap peserta didik mengerjakan soal yang telah diberikan. Bagi peserta didik yang bisa mengerjakan dengan jawaban yang tepat akan mendapatkan poin 2 (dua), yang bisa mengerjakan namun jawaban belum tepat akan mendapatkan poin 1 (satu), dan bagi peserta didik yang tidak bisa mengerjakan akan mendapat poin 0 (nol).

Berkaitan dengan hasil temuan peneliti guru memastikan tingkat pemahaman peserta didik dengan quipper school. Dalam proses penilaian kompetensi ini, kemampuan yang dinilai adalah bagaimana guru mampu menetapkan berbagai pendekatan, strategi, metode, dan teknik pembelajaran yang mendidik secara kreatif sesuai dengan standar kompetensi guru. Guru menyelesaikan metode pembelajaran supaya sesuai dengan karakteristik peserta didik dan memotivasi mereka untuk belajar.

Menguasai teori dan prinsip pembelajaran ditujukan guru matematika SMA Negeri 1 dengan melakukan aktivitas pembelajaran yang bervariasi dan memilih metode yang tepat agar meningkatkan motivasi belajar peserta didik. Pandangan tersebut sejalan dengan Russefendi dalam (Solihin, 2016, p.282) bahwa menerapkan teori pembelajaran dengan memilih metode yang tepat.

Mengacu pada revolusi industri keempat yang sudah merambah ke semua sektor harus disikapi dengan arif karena telah mengubah peradaban manusia secara fundamental, untuk itu diperlukan guru yang profesional, guru yang mampu memanfaatkan kemajuan teknologi informasi yang super cepat tersebut untuk meningkatkan kualitas proses belajar mengajar. Alat bantu mengajar (media pembelajaran) menjadi salah satu upaya guru untuk mengikuti perkembangan teknologi dalam pembelajaran yang menurut Sutopo, Pemanfaatan ICT secara terpadu di dalam pembelajaran yang memadukan berbagai keterampilan dan fungsi ICT di dalam proses belajar mengajar. Penggunaan ICT sebagai media pembelajaran dapat berbentuk file slide power point, gambar, animasi, video, audio. 
Perkembangan ICT memberikan kemudahan bagi para guru untuk meningkatkan profesionalisme. Selain dengan meningkatkan keterampilannya dalam menggunakan ICT dan memanfaatkannya untuk mendukung dan meningkatkan kualitas pembelajaran, para guru juga dapat meningkatkan wawasan dan pengetahuannya, pengetahuan tentang teori-teori belajar dan metode pembelajaran terbaru. Hal ini sepaham dengan Majid (2015, p.14) media pembelajaran perlu dipelajari guru sehingga mereka dapat menyampaikan materi pelajaran kepada peserta didik dan meningkatkan minat belajar peserta didik yang intinya media pembelajaran akan menunjang dalam proses pembelajaran.

Berkaitan dengan hasil temuan peneliti guru dapat menyusun silabus sesuai kurikulum yang dibuat bersama melalui forum MGMP selanjutnya merancang RPP dikembangkan guru sesuai dengan apa yang dinyatakan dalam silabus dengan kondisi di satuan pendidikan yang mencakup mata pelajaran, materi pokok, alokasi waktu, tujuan pembelajaran, KD dan indikator pencapaian kompetensi, materi pembelajaran, metode pembelajaran, media dan alat sumber belajar, langkah-langkah kegiatan pembelajaran dan penilaian.

Dari temuan peneliti dan didukung teori guru dapat menyusun silabus yang dibuat sesuai kurikulum melalui forum MGMP selanjutnya merancang RPP dikembangkan guru sesuai dengan apa yang dinyatakan dalam silabus dengan kondisi di satuan pendidikan yang mencakup mata pelajaran, materi pokok, alokasi waktu, tujuan pembelajaran, KD dan indikator pencapaian kompetensi, materi pembelajaran, metode pembelajaran, media dan alat sumber belajar, langkah-langkah kegiatan pembelajaran dan penilaian.

Dari temuan peneliti dan didukung teori guru melakukan aktivitas pembelajaran secara bervariasi dan memberi banyak kesempatan untuk bertanya, memberikan contoh, dan mempraktikkan soal-soal.

Guru harus memiliki kompetensi untuk melaksanakan pembelajaran yang mendidik dan dialogis. Hal ini berarti, bahwa pelaksanaan pembelajaran harus berangkat dari proses dialogis antar sesama subjek pembelajaran, sehingga melahirkan pemikiran kritis dan komunikasi. Tanpa komunikasi tidak akan ada pendidikan sejati yang menurut Mulyasa (2018, 75) mengemukakan bahwa:

Secara pedagogis, kompetensi guru dalam mengelola pembelajaran perlu mendapat perhatian, karena pendidikan Indonesia dirasa kurang berhasil, dinilai kering dari aspek pedagogis, dan sekolah tampak lebih mekanis sehingga peserta didik cenderung kerdil karena tidak mempunyai dunianya sendiri.

Dari pembahasan tersebut dapat disimpulkan bahwa menjadi tanggung jawab bersama guru dan peserta didik melalui sarana dialog. Proses dialog ini pun tidak boleh tertuju kepada guru saja, namun haruslah menjadi sebuah motivasi yang muncul dari guru atau peserta didik sehingga proses ini akan senantiasa merefleksikan antara pengalaman peserta didik dan guru.

Berkaitan dengan hasil temuan peneliti guru merancang bentuk penilaian sesuai tingkat kemajuan masing-masing peserta didik tetapi kurang optimal mengidentifikasi tentang bakat minat potensi peserta didik.

Guru harus mengembangkan peserta didik untuk mengaktualisasikan berbagai potensi yang dimilikinya. Selain menjadi tenaga pengajar yang profesional, guru juga berperan sebagai fasilitator dalam mengembangkan atau mengaktualisasikan berbagai bakat dan potensi yang dimiliki peserta didik sejalan dengan teori Ina Magdalena dalam (Danim, 2010, p.61) mengemukakan bahwa:

Betapa banyak peranan yang harus dilakukan oleh guru kepada siswa, maka seorang guru harus mampu membantu 
kesulitan-kesulitan yang dihadapi siswanya dalam proses pembelajaran terutama dalam menumbuh kembangkan bakat minat siswa. Hal ini sebagai simbol bahwa seorang guru diharuskan untuk mengembangkan bakat minat yang diminati.

Peran guru sebagai pembimbing artinya guru harus senantiasa memberikan kesempatan kepada peserta didik untuk mengonsultasikan berbagai kesulitan yang dihadapinya, baik ketika sedang berada di kelas maupun di luar kelas.

Dari temuan peneliti dan didukung teori guru berkomunikasi secara empatik dengan memberi perhatian dan mendengarkan semua pertanyaan dan tanggapan peserta didik dengan bersifat terbuka terhadap kritik, saran, pertanyaan dari semua peserta didik tanpa diskriminasi.

Kemampuan komunikasi adalah kemampuan yang harus dimiliki oleh seorang guru dalam melaksanakan kegiatan belajar mengajar. Kemampuan ini sangat diperlukan agar guru dapat mengelola peserta didik sekaligus tugas keguruannya, agar dapat mencapai tujuan yang telah direncanakan. Mengelola peserta didik artinya mengenali emosinya berarti mengelola dengan rasa empati terhadap apa yang dirasakan orang lain, yang akhirnya akan membuat komunikasi lebih efektif. Jamil (2016, p.36) menjelaskan bahwa komunikasi yang efektif adalah komunikasi yang bertujuan agar peserta didik dapat memahami pesan yang disampaikan oleh guru dan memberikan umpan balik yang sesuai dengan pesan. Umpan balik tersebut bisa berupa persetujuan maupun ketidaksetujuan, namun yang terpenting dari semua hal tersebut adalah dimengertinya pesan dengan benar oleh guru dan peserta didik.

Dari temuan peneliti dan didukung teori guru menyusun alat penilaian sesuai alat pembelajaran dengan berbagai teknik dan jenis penilaian tetapi tidak dilakukan analisis penilaian.
Penilaian pembelajaran yang dilakukan guru matematika terhadap kompetensi peserta didik meliputi penilaian proses dan hasil belajar. Penilaian proses pembelajaran dilakukan selama pembelajaran berlangsung pada setiap pertemuan dan beberapa pertemuan berikutnya sampai selesai dipelajarinya satu kompetensi dasar oleh peserta didik. Penilaian proses pada setiap pertemuan dapat dilakukan pada awal, tengah atau akhir pertemuan Dirman dalam (Kunandar, 2010, p. 12) menjelaskan bahwa komponen-komponen penting dalam sebuah pengajaran ada 4 (empat) di antaranya: tujuan, bahan, metode, dan alat penilaian. Semua komponen tersebut harus dipenuhi dalam proses belajar mengajar, karena setiap komponen saling berkaitan dan saling berpengaruh satu sama lain.

\section{KESIMPULAN}

Berdasarkan kajian teori, pembahasan temuan penelitian, maka dapat disimpulkan: 1. Guru memberi kesempatan yang sama kepada peserta didik untuk berpartisipasi aktif dalam kegiatan pembelajaran, dan belum optimal mengenali lebih dalam perkembangan anak didiknya (minat, bakat) yang beragam, 2. Guru memastikan tingkat pemahaman peserta didik dengan quipper school, 3. Guru dapat menyusun silabus sesuai kurikulum yang dibuat bersama melalui forum MGMP selanjutnya merancang RPP dikembangkan guru sesuai dengan apa yang dinyatakan dalam silabus dengan kondisi di satuan pendidikan yang mencakup mata pelajaran, materi pokok, alokasi waktu, tujuan pembelajaran, KD dan indikator pencapaian kompetensi, materi pembelajaran, metode pembelajaran, media dan alat sumber belajar, langkahlangkah kegiatan pembelajaran dan penilaian, 4. Guru melakukan aktivitas pembelajaran secara bervariasi dan memberi banyak kesempatan untuk bertanya, memberikan contoh, dan mempraktikkan soal-soal, 5. Guru 
merancang bentuk penilaian sesuai tingkat kemajuan masing-masing peserta didik tetapi kurang optimal mengidentifikasi tentang bakat minat potensi peserta didik, 6. Guru berkomunikasi secara empatik dengan memberi perhatian dan mendengarkan semua pertanyaan dan tanggapan peserta didik dengan bersifat terbuka terhadap kritik, saran, pertanyaan dari semua peserta didik tanpa diskriminasi, 7. Guru menyusun alat penilaian sesuai alat pembelajaran dengan berbagai teknik dan jenis penilaian tetapi tidak dilakukan analisis penilaian.

\section{DAFTAR PUSTAKA}

A.M, Sardiman. (2010). Interaksi dan Motivasi Belajar Mengajar. Jakarta: Rajawali Pers

Kunandar. (2010). Guru Profesional. Jakarta: Rajawali Press

Kurniawan, A. (2017). Deskripsi Kompetensi Pedagogik Guru dan Calon Guru Kimia SMA Muhammadiyah 1 Semarang. Jurnal Seminar Nasional Pendidikan, Sains dan Teknologi, vol 3 no 2 hal 1-7

Majid, Abdul. (2015). Pendekatan Ilmiah Dalam Implementasi Kurikulum 2013. Bandung: Remaja Rosdakarya

Mulyasa. (2018). Standar Kompetensi dan Sertifikasi Guru. Bandung: Remaja Rosdakarya

Solihin. (2016). Peningkatan Kompetensi Pedagogik Guru dan Kemampuan Akademik Siswa Melalui Lesson Study. Jurnal Pendidikan: Teori, Peneliti, dan Pengembangan, vol 1 no 11 hal 21-25

Sudarwan, Danim. (2010). Profesionalisme dan Etika Profesi Guru. Bandung: Alfabet

Sudarwan, Danim. (2013). Pengembangan Profesi Guru. Jakarta: Kencana

Sumaryaning R. Dewi. (2016). Analisis Kompetensi Pedagogik Guru Dalam Pelaksanaan Kurikulum 2013 Pada Pembelajaran Tematik Tema Sehat Itu Penting Kelas $\mathrm{V}$ di $\mathrm{SD} \mathrm{Hj}$. Isriati
Baiturrahman 1 Semarang Tahun Ajaran 2015/2016. Jurnal Ilmu Tarbiyah dan Keguruan, vol 1 no 4 hal 90-110

Suprihatiningsih, Jamil. (2016). Guru Profesional. Jogjakarta: Ar-Ruzz Media 